\title{
1. How to make 1500 holes in the ground: accounting for law alongside other place-shaping factors in the making of an exceptional Cold War network

\author{
Luke Bennett
}

\section{INTRODUCTION}

The last decade has seen an increasing interest in pragmatism within legal geography (Blomley 2014; Delaney 2010). Building upon legal geography's traditional concern with the investigation of how law, society and spatiality work alongside each other in the creation of places, the pragmatists seek to identify the practices and motives that inform these 'instrumental encounters with the environment' (Blomley 2014, p. 83). Blomley has pointed to the need for legal geographers to pay closer analytical attention to how law is used (or not used) as a space management technology and to the role of habit within this. For pragmatists, places are made for a reason and/or as a result of recursive practices. Whilst contemporary legal geography retains its concern to identify political or socio-economic power as a key driver in the materialisation of law into space (and thereby its constitutive role in creating places), the pragmatic analytical lens accepts that manifestations of particular types of place may not be driven by traditional models of power or conflict, or even fully conceptualised by their enactor. Thus, the turn to pragmatism, productively opens up scope to think about the local subjectivities and irrationalities of place-formation (Bennett 2019).

This interest in the idiosyncratic micro-dynamics and the unique circumstances of particular places reflects a general trend in human geography away from viewing place-making as simply the enacting of technocratic, uniform and 'cookie cutter'-based, top-down national (and/or systemic) processes. The mechanical simplicity of that notion of place-making has been rightly challenged by the work of Massey (2005) and urban regeneration scholars (Klemek 2011), who have shown that simply declaring a change of a site's character (and thereby making it a new type of place) is unlikely to succeed by that strategy alone. But the scholarship needs balance, for places are not always autonomous singularities. They are often categoric - they are local instantiations of legally defined 'place-forms' (such as 'factory', 'pub' or 'sidewalk') - and legal geographers are well placed to study how these place-forms are transposed into their local manifestations. This 'translocalisation' (Bennett 2016) is also a pragmatic process.

In a recent study (Bennett 2018) I used archival data in order to carry out a longitudinal, multi-site empirical investigation of the national and local pragmatics of translocalisation as featured in the roll-out across the United Kingdom (UK) between 1956 and 1965 of a network of 1500 small, identical underground monitoring posts. Following the Soviet Union's development of its hydrogen bomb in 1954 (and the realisation of nationwide vulnerability to drifting clouds of radioactive fallout in the event of an H-bomb attack), the UK Government imple- 
mented a nationwide roll-out of a new place-form, Royal Observer Corps (ROC) posts: small stations from which to monitor nuclear blast and radioactive fallout, which were constructed at intervals of 7-10 miles across the UK between 1956 and 1965 for the UK Monitoring and Warning Organisation (UKWMO). These posts were to be staffed in times of impending nuclear attack by local volunteer members of ROC. By examining individual Air Ministry files covering the construction and management of 100 of the ROC post sites in England, my study considered the way in which law was utilised, alongside other tools and pressures, to implement this array of localised but uniform points of presence for this national network.

Following the work of Jungk (1979) and Agamben (2005) we might assume that delivering an exceptional (and fundamentally existential) project like the ROC posts would entail invoking a highly directive, top-down, 'state of exception' (Agamben 2005): a milieu in which normal legal structures and constraints on power would be abandoned in order to respond to an emergency. And 'exceptional' is used repeatedly in this chapter in reflection of this perspective, not as a superlative but in this sense of exception-to-the-norm, both regarding the unusual object being created in response to the crisis (here ROC posts) and the non-standard manner of their creation within the emergency circumstance. However, using my study, in this chapter I present an alternative account of the nature and extent of law's actual role in this exceptional-seeming place-making project. My analysis draws upon Pruitt's (2014) theorisation of law's weaker presence in rural areas (which is where most ROC posts are located), and by detailing the pragmatics of both national and local aspects of serial place-making, I show how ordinary law (rather than any emergency laws) played a quiet, mundane (in the sense of uneventful, dull, prosaic) but present role, alongside other factors in the creation and subsequent management of the ROC posts.

\section{METHODOLOGY: THIS STUDY'S APPROACH TO GATHERING AND PRESENTING ITS DATA}

For my study I examined a random sample of 100 of the approximately 600 Air Ministry ROC post estate management files available in the National Archives, and I was able to supplement my sample with insights from a handful of landowner files obtained from other archives (which gave richer insight into the minutiae of Air Ministry/landowner relations) and published memoirs (which provided insight into the affective-material reality of ROC post building and ROC post dwelling). However, even when triangulated, these sources tended to present only fragments of the life-course of each site and no one 'real' site offered itself up as a complete case study, one which could showcase the entire 'rise and fall' life-cycle of this place-form. Therefore, in order to present a complete picture, I have consolidated my data into an ideal-type: a fictional - but characteristic and illustrative - site which I call 'Wasnott'. Whilst no single real site had as many things happen to it as this fictional site, each of the incidents are characteristic of the types of issues found to have arisen at various ROC posts. Thus, the aggregation of real events into the narration of the life story of a single fictional site is an analytical device and aggregation is the only artifice here.

Aggregation is a standard feature of analysis and the depiction of data, and research should strive to present its findings and argumentation in a way that aids effective consideration and communication. Thus, the fictionalisation here is a vehicle for aiding analysis and insight by creating a narrative (chronological and iterative) coherence, and also a density of events, 
through which the pragmatic interplay of local and national influences (and law's playing out within that) can be brought out into clear view. It is also a necessity in order to sustain a reader's attention: for ironically a faithful presentation of essentially mundane places, processes and concerns has to avoid being mundane in itself. ROC posts, whilst exceptional in their apocalypse-focussed purpose, were mundane in the nature of their modest form, the (in)frequency and improvised manner of their inhabitation and the matter-of-fact and down-to-earth arrangement of their legal existence. In short, at these sites nothing out of the ordinary (nothing exceptional) ever actually arose.

The following aggregated, fictionalised account then seeks to present an ideal-type of a ROC post site, a site at which more happened than at any single real site. Wasnott is thus made to speak for the UK's 1500 ROC posts, arrayed across the landscape at 7-10 kilometre intervals. These sites were built to a standard design, but also experienced degrees of local differentiation, as reflects the reality of any individual instantiation of a place-form. Places are products of storying: of cumulative and purposive meaning-making played out upon the landscape, and for ROC posts that storying played out simultaneously (and separately) at national and local level. The aim of the following is to show how the routine framings of everyday rural land management law played a role in forming and perpetuating these exceptional (but seemingly normalised) sites. Wasnott shows us that it was the familiar pragmatic practices of granting leases of fields, procuring maintenance contracts with local builders, undertaking rent negotiations with farmers and securing informal derogations from the burden of local authority parking byelaws that had the greatest shaping influence on these sites, rather than any special emergency powers characteristic of a state of exception. As the following storying of the Wasnott ROC post shows, sites were assembled iteratively, through a constantly reorganising assemblage of accumulated goals, practices and matter.

\section{RESULTS AND DISCUSSION: THE RISE AND FALL OF THE ROC POST}

\section{0}

We are at the verge of a country lane in the Hertfordshire countryside just outside the village of Wasnott, 30 miles north of London. Beyond a gap in the hedge a field gently rises to its brow on the horizon. Other than the stubble of an arable crop this field is empty; there is nothing to see here. The field is owned by the Parish Council but has been tenanted to a family of local farmers for three generations. The farmer regards the field as his land, but he will only visit it at sowing and harvest time. The field is known locally to be his. He does not need to actively assert, or qualify, his ownership.

\section{3}

Five men are standing in the field: the farmer, the head of the Observer Corps, the Clerk of the Parish Council, Wasnott's police constable and an engineer from the General Post Office (GPO). The Clerk is present because part of the field is now a recreation ground. The constable is here because his Chief Constable has been instructed via a 'confidential' standard form letter issued by the Home Office to arrange recruitment of local men as special constables to 
man an observation post to be established at this spot for the purpose of detecting, plotting and reporting aircraft movements as part of the air defence system. The procurement of both men and physical sites for the Observer Corps has become standardised through experience and repetition since the Corps was established as a volunteer force in 1924 in Kent and Sussex, and then slowly expanded across the counties of southern England. This field has been identified as suited to a post because it affords a good clear view towards London. However, the GPO engineer is in attendance because this location, at the edge of the recreation ground and adjacent to the farmer's field, is only feasible if a telephone connection can be run to it. The men agree a suitable position and a stake is driven into the ground.

As the Home Office's letter assures the Council, this stake is the post's only enduring physical element, for:

as the [observation] equipment is portable, nothing remains on the site when not in use, nor is there anything to be seen, except, in some cases, a peg driven in flush with the ground to mark the exact site, e.g. in a field ... A telephone pole may be erected close to the site, if no convenient pole already exists ... no damage of any sort occurs, and it may perhaps be mentioned that the men manning the post are always local men, known probably to you, and that in the quite large number of posts already established, no difficulties with Landlords or Tenants have been found to occur. (Home Office 1937, p. 1)

Accordingly, the Home Office's letter offers no rental payment for the post's use of the site, which it states will be used for annual exercises not exceeding seven days (or nights) per year. Through this mix of intra-governmental instruction, appeal to patriotic duty and assurance of minimal disturbance the Clerk agrees to waive any oppositions or formalities to the Home Office's scheme. Thus, the first iteration of Wasnott's ROC post is established on the basis of a bare licence, with minimum formality - in the light of the Home Office's assurance of the minimal impact upon the existing web of rural landownership relations.

\section{2}

After five years of open-air use, the Nazi invasion of Czechoslovakia in September 1938, provoked the Air Ministry into issuing designs for 'Standard Pattern Huts' and provided £5 to each post for materials by which shelter and welfare facilities could be locally sourced and erected. But in the face of rationing of building materials the roll-out of this solution was slow to bear fruit. As interim measures a tent and then a caravan were placed at the Wasnott site and then at the height of the Battle of Britain, amidst fears of imminent invasion, two members of the Home Guard camped out near the post in an old car they had dragged into the field. Eventually, in the summer of 1942, a wooden hut was finally delivered to the site, replete with an observation platform. The site is now occupied under the basis of a nominal lease, hastily drawn up on Air Ministry standard terms in September 1939. The Clerk felt that it would not have been conducive to the war effort to deny the Air Ministry full-time occupancy of the site for the duration of the war.

\section{6}

By the end of the war the site's hut was dilapidated and its materials scavenged, reflecting the dire shortage of construction materials at the war's end. Although quickly disbanded at the end of the Second World War, in the face of deteriorating relations with the Soviet 
Union in the Autumn of 1946, the Government decided that the ROC should be reactivated, and in December of that year, the Air Ministry wrote to Wasnott Parish Council proposing a year-to-year tenancy to formalise its resumption of occupation of the site. In the face of some resistance by the Council to the standard lease presented to them (but which the Air Ministry asserted had been accepted without amendment by many landowners), the Air Ministry and the Council eventually agree terms. In peacetime, it seems, an attentiveness to legal formalities can start to reassert itself. The Air Ministry appeals to a sense of national consistency and progress as a counter to the Council's instinct to approach negotiation of Wasnott's terms as a localised, site-specific matter.

\section{6}

The Chief Observer (the local post's senior officer) is sitting in his car, writing a letter to the Council thanking the councillors for their permission to bring cars onto the recreation ground for the duration of the one week summer training exercise. Following the previous year's exercise, a dispute had broken out between the Air Ministry and the Council. The Council had notified the Air Ministry of new byelaws prohibiting vehicles from the recreation ground and in turn the Chief Observer had alerted the Air Ministry that this restriction 'considerably dampened the enthusiasm of our Post Instructor and Observers', adding that 'it is no wonder that the ROC is struggling to attract volunteers' (Faulkener 1955, p. 1). After further correspondence a temporary concession was granted to permit the ROC volunteers to park their cars upon the site during their summer exercise.

Meanwhile, the subject matter of the post's training activity was set to change. In June 1955 the Home Secretary had announced to the House of Commons that steps were being taken for the ROC - given its network of observation sites spread across the length and breadth of mainland Britain - to give warning of and to measure radioactivity in the event of air attacks in a future war. Henceforth, instead of plotting aircraft the ROC would be plotting nuclear explosions and fallout.

Results from United States and UK testing in the mid-1950s had emphasised the importance of shelter in the face of not only blast, but also the ensuing fallout. Accordingly, in support of the ROC's new role the Government had authorised funding for the ROC posts to receive subterranean 'protected accommodation' (in the form of a small concrete bunker).

\section{0}

The local contractors are clearing the site, packing away the wooden shuttering planks used to form the poured concrete walls of Wasnott's subterranean protected accommodation. The shuttering will be used again at the next site, as they are all built to a standard design. As they drive out of the field the contractors are keen to do so quickly, before anyone from the Council appears. There has been recent correspondence between all parties about the mud churned up by the contractors' 'to-ing and fro-ing'.

Completed in early 1960, the building of Wasnott post's protected accommodation was the culmination of a protracted legal process that rather belies the urgencies of the Cold War arms race. Back in 1954 the Air Ministry had asked the Council to sell it the existing plot, but the Council had declined. After that, the Air Ministry had reconciled itself to meeting its needs by taking a 21 year lease of the site. Thereafter, from early 1955 until March 1959, a succes- 
sion of correspondence teased out mundane conveyancing matters concerning the nature of the Council's ownership interest in the site variously under the Wasnott Inclosure Act 1842, the need for Ministry of Education authorisation due to the recreation ground's educational endowment, negotiation of rent and fencing arrangements and steps to clarify the first names of all required signatories to the lease. Eventually, the lease was completed, regularising the Ministry's occupation of the site (now increased to 136 square yards) for 21 years and agreeing, at the Air Ministry's insistence, a 50 foot radius safeguarded area ringing the protected accommodation within which the landlord agreed not to build any obstructions (Air Ministry 1963).

\section{8}

The Defence Land Agent stands looking at the post and its environs, he is appraising the site's future viability. As manager of the Air Ministry's property assets in this area, Wasnott has been occupying more than its fair share of his time in recent years. Two years ago the site was the subject of a series of break-ins, resulting in damage to the access hatch and the two internal doors, and some equipment was taken. The police are unsure whether this was action by peace activists or vandalism by local children. Around the same time the Chief Observer reported that the tenant farmer's deep ploughing had encroached within one foot of one of the post's monitoring instruments. In response to these threats to the post the agent had been involved in instructing the Ministry of Public Building and Works to erect a six foot high galvanised chain link fence to form a 30 foot by 30 foot enclosed compound, with the post at the centre. The Council has recently sold the recreation ground to a housing developer and the post now sits adjacent to a building site. The tenant farmer is in negotiations with the developer to purchase the remainder of the field (including the land occupied by the ROC post). The agent has reminded the Council of the Ministry's extant lease and of the safeguarding zone within it. However, he is still concerned about the scope of encroachment and of obstruction of the field of view of the post's thermonuclear flash and blast detection instruments. Last year's devaluation of the pound against the dollar signalled a crisis of public expenditure, in the light of which the agent has been asked to identify ROC posts suitable for closure. Wasnott appears to be a good candidate.

A few days later, Prime Minister Harold Wilson announces to Parliament that the UK is to cease funding civil defence. The Civil Defence Corps and Auxiliary Fire Service are stood down, and funding reductions for the ROC require the post network to be halved to leave 870 posts, redistributed in reconfigured cells of three or four surviving posts, those posts now spread further apart. In Parliament questions are asked about what will happen to the closed posts, the reply being that 'the posts which are to be closed will be disposed of under the normal arrangement for surplus government property' (Ennals 1968, cc211-2W). But the reality is that many of the sites are leasehold (many with less than 10 years left to run on their tenancies), situated in the middle of nowhere and of little use other than as nuclear detonation monitoring posts. Most will be surrendered back to the landowner, with either the Air Ministry filling the post in and levelling its surface features, or a dowry paid to the landowner to cover the cost of them doing so after the post is handed over to them. However, a number of 'closed' posts will be held in reserve, experience having shown that flooding, trouble with anti-nuclear protestors or obstruction of post instruments by neighbouring development could all change the fortunes of any site, such that retention of a supply of locally available substitutes would 
be appropriate. Wasnott will suffer this fate: retained on a care and maintenance basis and added back into the network in 1973 when a nearby post falls victim to a bypass road-building scheme.

\section{6}

The two workmen from the Property Services Agency (PSA) have been on site for the last two days affixing polystyrene tiles to the walls and ceiling of the bunker. Visiting these posts the workmen have noticed that whilst built to a standard design, each post has its own subtle differences in the way that its volunteer crew have arranged it for their needs and comfort. At posts they have seen (and had to work around) a range of bespoke adaptations and augmentations made by the posts' crews: walls painted, curtains fitted to separate the bunks from the working area, fitting of carpet, signage, tool racks, clipboards and additional cupboards. The ROC turn a blind eye to such 'homemaking' by the post's crew. To discipline them for adapting the standard issue place-form would be counter-productive. The crew are volunteers and the priority is to keep them happy.

\section{0}

The Chief Observer is on site, inducting a new recruit and assuring him that his prospects for a long and enjoyable role in the ROC are buoyed by the Thatcher Government's stated commitment to reviving civil defence, in the face of a revival of Cold War tensions. But the ROC retains its perennial anxiety about recruitment and at Wasnott this anxiety colours the Chief Observer's stance around the renewal of the Wasnott Post's lease which is set to expire this year. The PSA (having now taken over the management of civil assets from the Defence Land Agent) has advised that the ROC can rely upon standard continuation of tenancy rights set down in the Landlord and Tenant Act 1954 which mean that the 1959 lease will be deemed to simply continue on its old terms, and that there is therefore no need to negotiate a new lease with the landowner. But the UKWMO's headquarters staff have become involved, and they share the Chief Observer's discomfort with this legally correct but passive approach. They all want something tangible and readily intelligible to prove to the volunteers that this post will be able to stay open. Assurance that rights under the 1954 Act already cover the point is too abstract. Ultimately, UKWMO will insist that the PSA enter into negotiations with the farmer (who now owns the site) to secure the active grant of a new 21 year lease because "we know from experience that any uncertainty about the long-term future of a post will have an adverse effect upon the morale of its crew' (UKWMO 1984, p. 1).

\section{2}

The Chief Observer places equipment removed from the post into the back of the hired van; it is now sixth months after the formal standing down of the ROC. In July 1991 the Home Secretary had suddenly announced that following a review of the defence requirements in the light of the fall of the Berlin Wall, the Home Office could no longer justify the continued use of the ROC volunteers for the nuclear monitoring role, and that this responsibility would in future be met by a mixture of local authorities and the military. The news had been received with shock by the ROC. At Wasnott the observers had gathered at the site for the last time 
and written their names, and the date, upon the wall of their post. Due to the suddenness of the abandonment, and the remoteness of the site, much is left in situ entombed within the abandoned post.

\section{9}

Accompanied by the bemused farmer, the man with the expensive-looking camera climbs down into the Wasnott post. The photographs that he takes there will form part of a survey which will present online an account of the location and physical state of every traceable ROC post. The farmer acquired this field from the Council after the recreation ground was sold for housing development in 1967. He had never paid much attention to it prior to the ROC stand-down. In 1992 he had accepted surrender of the lease and a payment of $£ 50$ in lieu of the reinstatement liability. Shortly afterwards he took the post's fencing down. But otherwise he had left things alone. To the farmer the former ROC post was simply a small area of concrete in the corner of one of his fields: unremarkable and unimportant as long as it didn't affect ploughing or harvesting.

A few years later he had been approached by a businessman who said that he would like to rent the bunker as a weekend retreat. The farmer had seen the man on site a few times, cutting the grass around the post or sitting on the hatch admiring the view of London. One time in conversation the man had declared: 'this place was originally built so the Royal Observer Corps could monitor London being wiped off the map. Sometimes that's easy to forget' (quoted in Arnot 2001, n.p.), as if he was trying somehow to resist that forgetting. But the man's attendance had tailed off after a while and he eventually stopped paying the rent. The farmer had not bothered to chase the man for continued payment or formal surrender of his lease.

\section{7}

Using now readily available locational data the enthusiast has programmed his sat-nav to alert him of proximity to any ROC post. Having detected one here, on the outskirts of Wasnott, he strolls across the field and down into the bunker. He has acquired a special key on eBay with which he can open the standard-form hatch lock. He does not care that he is a trespasser. He knows that it is unlikely that anyone will see him enter the post, let alone object to him doing so. He regards his interest in this place as of public benefit (here see interpretations of bunker hunter motives in Bennett 2017) - justified by the post's heritage status, now that the material culture of the Cold War era is becoming seen as 'history' (for example through the heritage valorisation of it performed by Cocroft and Thomas 2004). Descending into the bunker he finds a burnt-out shell. The man takes some photos which he later uploads to an urban exploration forum website, describing his visit thus: 'close to minor road and OPEN. As previously reported - empty and burned. Nasty. The site is overgrown and is being undermined by rabbits' (28 Days Later 2010, n.p.).

\section{3}

The farmer has decided to clear away the Wasnott post's surface features, having heard recently that English Heritage had listed a ROC post in Yorkshire (Subterranea Britannica 2002) (and thus accorded it statutory protection against alteration or demolition) after enthu- 
siasts had restored it. The farmer wants to ensure that his site doesn't attract any heritage designations that might restrict his use of his land. His insurance broker has also worried him by pointing out that he would be liable if anyone were to be injured within the post.

Erasure of the post is easy. The turrets fall with the aid of a towrope and a tractor, and he then grubs out the near-surface remains of the hatch, tumbling the masonry into the ladder well. Thereafter, overfilling the smashed remains with soil leaves no trace of the ROC's former presence in this now empty field.

\section{9}

And now all that remains to speak of the instantiation of this war-related place-form at this site are the fragments of land management documentation in the site's Air Ministry file. These documents give glimpses of its place-law elements intertwined with governmental policies: a translocalisation that shaped the fate of this place-form either generally or at this location. These off-site, archival traces are all that remain to detail the making, maintaining and abandoning of a small lookout post once set up in the middle of this countryside, as a localised embodiment of the heady swirl of an earlier era's geopolitical anxieties. And here in this out-of-the-way corner of a field, for a period of time that is now 'the past', an underoccupied, approximate and contingent place weakly existed - a place occasionally activated by maintenance visits and weekend training exercises, and one elsewise only signalled by rudimentary fencing and signage. Here, in ebb and flow at the site, people came and went, matter was added to or subtracted from it and legal rights were acknowledged or ignored: in each case, as seemed fitting to the pragmatic orientation of the actors at any particular moment.

\section{DISCUSSION: WHAT DOES WASNOTT TELL US ABOUT LAW, LOCALITY AND PLACE-MAKING?}

Any place is a blend of local specifics and wider-ranging generalities. Thus, the above account shows that the roll-out of the Cold War's ROC post network was the outcome of an interplay between local pragmatic meanings and action (that is, a keenness to adhere to mundane rurality), and each site's enrolment in wider (equally pragmatic) frameworks born of non-local meanings, place-making processes and/or goals (i.e. a state's preparation for nuclear war). Perhaps surprisingly, in the roll-out of this network national exigencies did not appear to subsume the timeless rural specificities of the local. Instead, as the Wasnott account has shown, 'apocalyptic contingencies were subsumed within the mundane demands of the here-and-now, and its cows, farmers and mud' (Bennett 2018, p. 222). But this is not to claim that this national place-form replicating project failed, for the 1500 subterranean posts did still get built, and this was achieved through a successful translocalisation of the ROC post place-form.

Thus, the Wasnott account has not been presented as a salutary warning about (or celebration of) the resistive potency of local specificity, nor has it been seeking to assert the uniqueness of any single place's experience of the roll-out. Instead the aim has been to show how the goals of this national project were achieved through a (nationally) pragmatic manoeuvre: working with the grain of the existing rural milieu, rather than seeking to impose something exceptional (a nuclear war-monitoring network) via exceptional means. Thus, the Wasnott 
account, as a more-eventful-than-most, fictionalised version of a ROC post site's life story, has been presented in order to give salience to this quiet but persistent adaptation of the national project to local ways of doing, as it played out at a (generic) local level in order to deliver the network. This, however, was not a strategy explicitly selected at national level - the result of an expert committee thinking through what would work best given the likely challenges that the roll-out might face. Instead, this accommodating approach was adopted more by accident than by design. It was simply a function of placing the ROC post roll-out in the hands of the Air Ministry's existing land agents, as they were more used to negotiating prosaic leases and wayleaves for airfield drainage and such like, rather than planning for nuclear war.

The project also succeeded because many of the sites at which the Cold War's ROC posts were to be sited already had an association with previous ROC use - and this created both a familiarity between the parties, and an expectation that the manner of dealing would continue to be in the mundane mode with which all parties were already familiar. Accordingly, the Wasnott account did not begin with the start of the protected accommodation programme in 1956, instead it traced the story back through earlier eras of ROC observation post creation, following the First World War. Furthermore, in order to trace the local/national interplay across the full life-cycle of ROC posts, the Wasnott account did not end in 1965, the year in which the network's construction works were completed, but instead portrayed the ongoing fate of these place-forms up to their present-day dereliction.

The account shows how some - albeit approximate, habituated - regard was had to law as part of the composition and management of these places across their entire lifetime, but that the law in question was that of the familiar laws and practices of rural land management, rather than recourse to any emergency powers legislation (such as those of land requisition, or the martial direction of labour or resources). Thus rather than finding evidence of a 'state of exception' (Agamben 2005) (or the warping of normality by the exceptional needs of a 'nuclear state', Jungk 1979), the ROC post roll-out shows a 'softly softly' approach, such that:

at the level of implementation [of the roll-out] the character and problems of these sites were the problems of small land possessions or wayleaves held in support of infrastructural purposes in remote fields. The establishment and maintenance of the ROC post network at the height of the Cold War presents then as just another set of mundane rural land administration problems, with the solutions guided by standard country ways of doing. (Bennett 2018, p. 221)

The vast majority of ROC posts were situated in the British countryside (due to the need for nationwide coverage and the best lines of sight) and this 'country ways of doing' was evident in both the dispositions of the Air Ministry's land agents and the expectations of their counterparts, the rural landowners. Each had existing ways of interacting, and conventions for negotiating matters relating the use of their land. The exceptional purposes of the ROC posts did not affect this, instead these (approximately) 5 square metres required land plots were rendered down to the concerns and processes of conventional rural land negotiations. Formal legal rights formed only an approximate consideration - legal processes and considerations were often overridden by other habits and concerns.

Pruitt (2014) has offered us a view that law's grip is weaker in rural areas: for here space is less occupied, and law (and its related symbolism) is less reinforced. So, extending Pruitt's claim, we can see why law's directive grip might be weaker in place-making schemes carried out in the countryside. The Wasnott account's life-cycle, longitudinal approach, helps to show why ROC posts' distinctiveness as place-formations separate from the identity of the land all 
around and above them (i.e. rural land) was of variable consistency, as changing geopolitical circumstances called them in and out of use or significance. Furthermore, given the fact that the ROC post sites were a type of place that was never fully implemented or occupied (i.e. because it was a place designed only to be useful in the event of a nuclear attack), it is not perhaps surprising to find law's grip on the situation of place to be even weaker. Thus ROC posts need to be understood as largely contingent places, for most of the time they were empty: empty of people, largely empty of visible structures (because the posts were mostly below ground) and perhaps, therefore unsurprisingly, largely legally 'empty', except in those occasional instances where the needs of the 'ROC post' place-form caused friction with those of the place-form 'rural land'. Generally, ROC posts struggled to occupy enough time or space at their sites to fully stamp the contingencies of national defence (or sometimes even the strict formalities of law) upon the array of actors and mundane circumstances that often threatened to subsume them.

\section{CONCLUSION}

The Wasnott account shows how law helps to define and impose place-forms, but also that it is not the only shaping influence. Indeed, the account has shown various ways in which the strict formalities or extent of rights conferred by law were curbed or approximated in the interests of other priorities. Thus, the strength of law's contribution to the assemblage of place-making elements has been shown to be affected by changing circumstances and intensities across time. Socio-legal scholars desire to resist the assumption of law's dominion or closure, and thus would recognise this acknowledgement that law is not always in the driving seat. However, law-based studies struggle to cope with situations which appear to be out-with law's domain, for how can law's mundanity or marginality be written of in scholarship concerned with law's effects? The foregoing account has sought to show that it is precisely those situations of law's seemingly marginal or unexpectedly mundane presence within place-forming that need exploring and accounting for in legal geography.

\section{REFERENCES}

28 Days Later (2010), 'Entry for a 2010 visit to the burnt out ROC Post at Ickleton, Essex', accessed 23 May 2019 at www.28dayslater.co.uk/ickleton-roc-post-essex-group-march-2010.t48119

Agamben, Giorgio (2005), State of Exception, trans. Kevin Attell, Chicago: University of Chicago Press. Air Ministry (1963), '20 May 1963 lease for Ickleton ROC Post', Ickleton Society's Archives, accessed 23 May 2019 at www.ickletonvillage.co.uk

Arnot, Chris (2001), 'Bunker mentality', The Telegraph, 17 March, accessed 23 May 2019 at www .telegraph.co.uk/finance/property/4813394/Bunker-mentality.html

Bennett, Luke (2016), 'How does law make place? Localisation, translocalisation and thing-law at the world's first factory', Geoforum, 74, 182-91.

Bennett, Luke (ed.) (2017), In the Ruins of the Cold War Bunker: Affect, Materiality and Meaning Making, London: Rowman and Littlefield International.

Bennett, Luke (2018), 'Cold War ruralism: civil defense planning, country ways, and the founding of the UK's Royal Observer Corps' Fallout Monitoring Posts network', Journal of Planning History, 17 (3), 205-25.

Bennett, Luke (2019), 'The haunted paddock: exploring the roots of an ambiguous urban greenspace', People, Place and Policy, 12 (3), 225-340. 
Blomley, Nicholas (2014), 'Learning from Larry: pragmatism and the habits of legal space', in Irus Braverman, Nicholas Blomley, David Deaney and Alexandre Kedar (eds), The Expanding Spaces of Law: A Timely Legal Geography, Stanford, CA: Stanford University Press, pp. 77-94.

Cocroft, Wayne D. and Thomas, Roger J. C. (2004), Cold War: Building for Nuclear Confrontation 1946-1989, Swindon: English Heritage.

Delaney, David (2010), The Spatial, the Legal and the Pragmatics of World-Making: Nomospheric Investigations, London: Routledge.

Ennals, David (1968), 'Home Department minister, David Ennals' written response to a written question posed by Stanley McMaster', Hansard, HC Deb 1 May 1968 vol 763 cc211-2W, London: HMSO.

Faulkener, H. (1955), 'Letter from Chief Observer, H. Faulkener to ROC Group 14 HQ, 28 March 1955', Kingsclere Parish Council 19M76/PX30 (council correspondence relating to the Kingsclere ROC post, 1935-1966), Winchester: Hampshire County Council Records Office.

Home Office (1937), 'Letter dated 7th October 1935 to Kingsclere Parish Council', Kingsclere Parish Council 19M76/PX30 (council correspondence relating to the Kingsclere ROC post, 1935-1966), Winchester: Hampshire County Council Records Office.

Jungk, Robert (1979), The Nuclear State, trans. Eric Mosbacher, London: John Calder.

Klemek, Christopher (2011), The Transatlantic Collapse of Urban Renewal: Postwar Urbanism from New York to Berlin, London: University of Chicago Press.

Massey, Doreen (2005), For Space, London: SAGE.

Pruitt, Lisa R. (2014), 'The rural lawscape: space tames law tames space', in Irus Braverman, Nicholas Blomley, David Deaney and Alexandre Kedar (eds), The Expanding Spaces of Law: A Timely Legal Geography, Stanford, CA: Stanford University Press, pp. 190-214.

Subterranea Britannica (2002), 'Brandsby ROC Post', accessed 7 November 2019 at www.subbrit.org .uk/sites/brandsby-roc-post/

UKWMO (1984), 'Letter from K.P. Trotter (UKWMO, Oxford) to Miss K.L. Jones, (PSA, Bristol), 13 August 1984', NA AIR2/19432 (Amesbury ROC Post), London: National Archives. 